\title{
Differentiation of barley yellow dwarf luteovirus serotypes infecting cereals and maize in Hungary
}

\author{
E Pocsai ${ }^{1 *}$, G Kovács ${ }^{2}$, I Murányi ${ }^{3}$, Á Orosz ${ }^{4}$, M Papp ${ }^{5}$, L Szunics ${ }^{4}$ \\ 1 Plant Health and Soil Conservation Station of County Fejer, H-2481 Velence; \\ 2 Cereal Research Institute, H-9761 Táplánszentkereszt; \\ ${ }^{3}$ Rudolf Fleischmann Agricultural Research Institute of the Gödöllö University of Agricultural Sciences, H-3356 Kompolt; \\ ${ }_{4}^{4}$ Agricultural Research Institute of the Hungarian Academy of Sciences, $\mathrm{H}-2462$, Martonvásár; \\ 5 Cereal Research Institute, H-6726 Szeged, Hungary
}

(Received 15 May 1995; accepted 3 July 1995)

\begin{abstract}
Summary — In 1994, a survey was carried out at 4 different locations in Hungary (Kiszombor, Kompolt, Martonvásár and Táplánszentkereszt) for the presence of barley yellow dwarf luteovirus (BYDV) serotypes in barley, wheat, triticale and maize. Leaf samples exhibiting symptoms of barley yellow dwarf virus were collected from cereal and maize plants. The number of samples collected was 119 from barley, 297 from wheat, 92 from triticale and 274 from maize. Diagnosis was done by double antibødy sandwich enzyme-linked immunosorbent assay (DAS-ELISA), using RPV, RMV, MAV, PAV and SGV diagnostics (Agdia). We determined that, among the barley yellow dwarf luteovirus serotypes, the PAV serotype was dominant in cereals at all locations. In maize both the RPV and RMV serotypes were present at high rates.
\end{abstract}

luteovirus / barley yellow dwarf / serotype / cereal / maize

Résumé - Différenciation des sérotypes du virus de la jaunisse nanisante de l'orge (BYDV) qui infectent les céréales et le maïs en Hongrie. En 1994, une enquête a été réalisée dans 4 localités de Hongrie (Kiszombor, Kompolt, Martonvásár et Táplánszentkereszt) pour étudier la présence des sérotype du BYDV chez les orges, blé, triticale et maïs. Des échantillons de feuilles montrant des symptômes du BYDV ont été prélevés sur des plantes de céréales à paille et de maïs : 119 d'orge, 297 de blé, 92 de triticale et 274 de mais. Le diagnostic viral par la méthode DAS-ELISA (double antibody sandwich enzyme-linked immunosorbent assay) a été utilisé pour les virus : RPV, RMV, MAV, PAV et SGV. Les résultats montrent que, parmi les sérotypes du BYDV, c'est le PAV qui est dominant dans les céréales des différentes localités. Chez le mais, les sérotypes RPV et RMV sont présents à des taux élevés.

lutéovirus / barley yellow dwarf / sérotype / céréale / maïs

\section{INTRODUCTION}

Barley yellow dwarf luteovirus (BYDV) is an economically important aphid-borne and phloemrestricted virus that occurs world-wide in cereals. It is also distributed widely in perennial grasses.

In Hungary barley yellow dwarf luteovirus is one of the greatest limiting factors in barley and wheat production. This virus was first identified and described in winter barley by Szirmai (1967). Five years later it was observed in winter wheat during the spring of 1972 by Szunics and Szunics (1980). This virus was later recorded in maize by Milinkó et al (1984) and in rice by Pocsai et al (1985). In spite of the fact that BYDV was first found in only 1967, it has become the most

\footnotetext{
${ }^{*}$ Correspondence and reprints
} 
important virus pathogen of cereal crops in Hungary. Major infections in cereals were recorded in 1976, 1980, 1982, 1986 and 1989.

In 1982 a very severe epidemic occurred in barley. Yield losses caused by BYDV ranged from 27 to $100 \%$ in the different barley varieties (Pocsai and Kobza, 1983).

Five strains or serotypes of the pathogen have been differentiated on the basis of vector specificity and serological properties. Rochow (1969) differentiated 4 types of isolate: RMV, RPV, MAV and PAV. Isolates of the RMV type were transmitted regularly and specifically by Rhopalosiphum maidis and less frequently by $R$ padi, Macrosiphum avenae and Schizaphis graminum. The role of $R$ padi is decisive in the transmission of RPV. MAV was specifically transmitted by $M$ avenae and rarely by $R$ padi, $R$ maidis and $S$ graminum. PAV could be transmitted regularly but not specifically by $R$ padi and $M$ avenae.

In Manitoba, Gill (1969) described a fifth variant of BYDV which was specifically transmitted by $S$ graminum.

For a long time the aphid transmission test was the only way to differentiate between the barley yellow dwarf virus strains. At that time this comparative transmission test allowed confirmation of the field diagnosis of the disease and provided information about the relative distribution of BYDV variants. However, the aphid transmission test is tedious and time consuming, and relatively few samples can be tested during the growing season.

Rochow and Muller (1971) reported the occurrence of a fifth major variant of BYDV in New York state. Until 1969, all BYDV isolates encountered in New York could be grouped within 1 of 4 major variants. This fifth variant appeared to be similar to isolates transmitted specifically by $S$ graminum described in Manitoba by Gill (1969).

Recently, strain-specific antisera have been available for the differentiation of BYDV serotypes.

Aapola and Rochow (1971) used the immunodiffusion test in agar gel and the Latex agglutination test for the differentiation of the BYDV strains. Paliwal (1977) developed a serologically specific electron microscope method. This procedure was used for the rapid detection of the virus in small samples of several cereals and grasses.

The results obtained indicated a serological relationship between both non-specific and SGVspecific isolates and the MAV isolate antiserum.
However, the RPV- and RMV-specific isolates seemed to have a few antigens in common with the MAV-specific isolate.

Rochow $(1979,1982)$ compared the results of the aphid transmission test with those of obtained using ELISA. In comparison with the aphid transmission test, the ELISA was simpler, more sensitive, and took less time. The ELISA test was especially better for the diagnosis of mixed infections.

Lister and Rochow (1979) indicated that ELISA was sensitive enough to detect BYDV in oat leaf extracts. ELISA could easily distinguish between RPV and MAV. PAV sometimes reacted weakly with MAV antiserum in heterologous tests.

The ELISA procedure was successfully applied for the detection and differentiation of BYDV serotypes by Gugerli and Derron (1981), Rochow (1982), Hammond et al (1983) and Haase et al (1985). Among the serotypes of BYDV there are differences in the degree of damage caused by the virus.

Al-Faiz et al (1993) observed that cereals infected by BYDV were highly sensitive to drought in field trials. It was detected that the root length of plants infected by BYDV was much shorter than that of the healthy control. The PAV serotype proved to be the most aggressive while MAV had a less severe effect on the root length. Their experiments showed that barley roots were more severely injured by BYDV than wheat and oat roots.

Bertschinger (1993) studied the response of 7 bread wheats and 3 barley genotypes to 4 Mexican BYDV serotypes. Among the virus serotypes, the highest yield reductions were recorded for the PAV and MAV serotypes in Mexico.

Webby et al (1993) carried out ELISA-based surveys of maize crops in Mexico using polyclonal antisera to the MAV, PAV, SGV, RPV and RMV serotypes of BYDV. They found that RMV was the most common serotype in maize.

The occurrence of BYDV serotypes in Hungary has not been studied previously. Conclusions about the presence of BYDV serotypes were drawn from populations levels of the different aphid species. Szirmai $(1967,1974)$ emphasised the role of $R$ padi, $R$ maidis and $M$ avenae in the transmission of BYDV. Bisztray et al (1985) recorded the fact that $R$ padi was the main vector of BYDV, representing $70 \%$ of the total vector from population. Other species, such 
as $M$ avenae (10\%) and $R$ maidis ( $5 \%$ ) were also present but their role in virus transmission was smaller. In Hungary BYDV is fairly frequent in cereals and maize. Its importance is proved by a number of publications (Szirmai, 1967, 1974, 1977, 1987; Szunics and Szunics, 1980, 1984; Szunics et al, 1983, 1988, 1991; Pocsai et al, 1983, 1985; Pocsai and Kobza, 1983; Milinkó et al, 1984; Nagy and Milinkó, 1984, 1986; Pocsai and Szirmai, 1985; Pocsai, 1988; Gáborjányi, 1992). A knowledge of the different serotypes of BYDV occurring in Hungary would provide useful information for plant breeders. Therefore, this topic was examined at different locations in Hungary.

\section{MATERIALS AND METHODS}

In 1994, a survey was carried out at 4 different locations in Hungary (Kiszombor, Kompolt, Martonvásár and Táplánszentkereszt) for the presence of BYDV serotypes in barley, wheat, triticale and maize. In Kiszombor (in the southern part of Hungary) 12 varieties of winter wheat were tested. Twenty leaf samples showing symptoms of BYDV were collected from each variety for the serological tests. In Kompolt (north Hungary) 8 winter barleys and 2 spring barleys were tested. Ten leaf samples exhibiting symptoms of BYDV were collected from each variety. In Martonvásár (in the middle part of Hungary), 19 winter barley, 57 winter wheat, 92 triticale and 220 maize plants showing viral symptoms were tested. In Táplánzentkereszt (west Hungary) 54 maize plants showing symptoms were tested for the presence of BYDV serotypes.

Leaf samples were collected in nylon sacks. The next day the samples were homogenized using a leaf press machine with the addition of a sample buffer solution in a ratio of $1: 10$.

Virus diagnosis was made using DAS-ELISA (Clark and Adams, 1977) using RPV, RMV, MAV, PAV and SGV diagnostics. Serological reactions were evaluated using a Labsystems Multiskan Plus photometer at $405 \mathrm{~nm}$.

\section{RESULTS}

The results of serological tests on the 12 varieties of winter wheat collected at Kiszombor are shown in table I. The data in the table show that 8 of the 12 varieties of winter wheat proved to be infected by BYDV. In these 8 varieties 32 plants were found to be infected. The measure of infection varied from 5 to $45 \%$ in the infected varieties.

The differentiation of BYDV serotypes in the infected wheat samples is shown in table II. In the southern part of Hungary the RPV, RMV, PAV and SGV serotypes occurred in winter wheat. PAV was dominant in the BYDV serotypes. Besides the PAV serotype, RMV was present at fairly high rates. This was the only location where SGV was found in cereals.

Table III shows the results of serological tests on winter and spring barley samples collected at Kompolt (north Hungary). The data in the table illustrate that there was no severe infection by BYDV in 1994. Only 7 of the 100 samples were positive for BYDV. The infection of BYDV was higher in the spring barleys than in the winter ones.

Table I. Results of serological tests on winter wheat samples collected at Kiszombor (south Hungary). 
Table IV shows the differentiation of BYDV serotypes in the infected barley samples. In the northern part of Hungary only 2 serotypes occurred in barley. These were PAV and RMV. From the data of the serological tests, it is obvious that the PAV serotype was the most preva- lent. This serotype was present in all infected samples of barley. RMV occurred in one sample only.

The results of serological tests on samples collected in Martonvásár (central Hungary) are shown in table $\mathrm{V}$.

Table II. Differentiation of BYDV serotypes in infected wheat samples collected at Kiszombor.

Variety $\quad$ No of samples infected by BYDV

\begin{tabular}{ccccc}
\multicolumn{5}{c}{ Differentiation of $B Y D V$ serotypes (No of samples) } \\
\hline RPV & RMV & MAV & PAV & SGV \\
& & & & \\
0 & 0 & 0 & 3 & 0 \\
0 & 1 & 0 & 0 & 0 \\
0 & 0 & 0 & 2 & 0 \\
1 & 2 & 0 & 4 & 0 \\
0 & 7 & 0 & 1 & 1 \\
0 & 0 & 0 & 1 & 0 \\
1 & 0 & 0 & 1 & 0 \\
1 & 2 & 0 & 5 & 0 \\
3 & 12 & 0 & 17 & 1 \\
& & & & \\
\hline
\end{tabular}

Table III. Results of serological tests on barley samples collected at Kompolt (north Hungary).

Variety

No of samples tested

No of samples infected by BYDV

K-17 winter barley

$\mathrm{K}-85 / 24$ winter barley

$\mathrm{K}-83 / 25$ winter barley

K-89/68 winter barley

K-7 winter barley

$\mathrm{K}-87 / 27$ winter barley

$\mathrm{K}-13$ winter barley

Orbit spring barley

Nóra spring barley

Total

3
1
2
7
9
1
2
7
32

Table IV. Differentiation of BYDV serotypes in infected barley samples collected at Kompolt.

\begin{tabular}{|c|c|c|c|c|c|c|}
\hline \multirow[t]{2}{*}{ Variety } & \multirow[t]{2}{*}{ No of samples infected by BYDV } & \multicolumn{5}{|c|}{ Differentiation of BYDV serotypes (No of samples) } \\
\hline & & $R P V$ & $R M V$ & MAV & PAV & SGV \\
\hline$K-89 / 68$ & 1 & 0 & 0 & 0 & 1 & 0 \\
\hline $\mathrm{K}-87 / 27$ & 1 & 0 & 1 & 0 & 1 & 0 \\
\hline $\mathrm{K}-13$ & 2 & 0 & 0 & 0 & 2 & 0 \\
\hline Orbit & 2 & 0 & 0 & 0 & 2 & 0 \\
\hline Nóra & 1 & 0 & 0 & 0 & 1 & 0 \\
\hline Total & 7 & 0 & 1 & 0 & 7 & 0 \\
\hline
\end{tabular}


The number of samples collected was 19 from barley, 57 from wheat and 92 from triticale. In barley only 2 of the 19 samples were found to be infected by BYDV. The highest infection occurred in triticale, in which 10 of the 92 samples collected proved to be infected by BYDV.

The measure of infection ranged from 0 to $10 \%$ in the different cereals. Table VI shows the differentiation of BYDV serotypes in the infected samples. In the middle part of Hungary, the PAV and RPV serotypes were present in cereals. In barley, PAV was the only serotype which occurred in all the infected samples. In triticale the PAV serotype was found together with RPV in mixed infection. In the middle part of Hungary, the PAV serotype was the most widespread in the different cereal crops.

The results of serological tests on the 11 maize lines collected in Martonvásár are shown in table VII; 220 samples were collected from maize and, according to the results of the serological test, 35 samples were positive for BYDV. Different symptoms were observed in the various maize lines tested. BYDV was present in almost all tested lines of maize, with the exception of one line.

The measure of infection varied from 10 to $40 \%$ in the infected maize lines. Table VIII shows the differentiation of BYDV serotypes in the infected samples of maize. In Martonvásár, 3 serotypes were present in maize; RPV, RMV and
MAV. Among these serotypes, RPV and RMV occurred at the highest rate.

The results of the differentiation of BYDV serotypes in maize samples collected in Táplánszentkereszt are presented in table IX.

In the western part of Hungary, 18 of the 54 samples collected were found to be infected by BYDV according to the results of the serological test. In Táplánszentkereszt 4 serotypes were present in maize. The incidences of RMV, PAV and RPV were the highest. Besides the RMV and RPV serotypes, the occurrence of PAV was surprisingly high in maize.

The results of serological tests on the different cereal species are summarized in table $X$.

In barley 9 samples were positive for BYDV. In these only the PAV and RMV serotypes were present. The PAV serotype was the most prevalent, occurring in every infected sample. PAV serotypes were present in $100 \%$ of the samples, followed by RMV in $11 \%$ of the samples.

In wheat 32 samples were found to be infected by BYDV. Four serotypes were present. The PAV serotype was dominant in all locations with an incidence of $53 \%$, followed by RMV $(37 \%)$. The incidences of RPV and SGV were relatively low, with percentages of 9 and $3 \%$ in the infected samples.

Table V. Results of serological tests on samples of winter barley, winter wheat and triticale collected in Martonvásár.

Variety

No of samples tested
No of samples infected by BYDV
Winter barley

Winter wheat

Triticale

Total
19

57

92

168
2
0
10
12

Table VI. Differentiation of BYDV serotypes in infected cereals collected in Martonvásár.

Variety

No of samples infected by BYDV

\begin{tabular}{|c|c|c|c|c|}
\hline$R P V$ & $R M V$ & $M A V$ & PAV & SGV \\
\hline 0 & 0 & 0 & 2 & 0 \\
\hline 4 & 0 & 0 & 7 & 0 \\
\hline 4 & 0 & 0 & 9 & 0 \\
\hline
\end{tabular}


In triticale PAV serotypes were the most widespread. These were found at a ratio of $70 \%$. RPV was present in $40 \%$ of the infected samples.

In maize 53 samples were positive for BYVD and 4 serotypes could be detected. The inci- dences of RPV and RMV were the highest, with percentages of 49 and $47 \%$. MAV and PAV only occurred in mixed infections, in 20 and $15 \%$, respectively. The results show that in cereals the PAV serotype was dominant in all locations while MAV did not occur at all in 1994.

Table VII. Results of serological tests on maize samples collected at Martonvásár.

Variety

No of samples tested

\section{No of samples infected by BYDV}

Mvir-1

Mvir-2

Mvir-3

Mvir-4

Mvir-5

Mvir-6

Mvir-7

Mvir-8

Mvir-9

Mvir-10

Mvir-11

Total

Table VIII. Differentiation of BYDV serotypes in infected maize samples collected at Martonvásár.

\section{0}

20

20

20

20

20

20

220

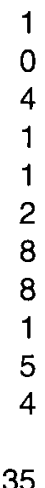

35

1
0
4
1
1
2
8
8
1
5
4

Differentiation of BYDV serotypes (No of samples)

RPV RMV

Mvir-1

Mvir-2

Mvir-3

Mvir-4

Mvir-5

Mvir-6

Mvir-7

Mvir-8

Mvir-9

Mvir-10

Mvir-11

Total
No of samples infected by BYDV

1
0
4
1
1
2
8
8
1
5
4

35 
Table X. Occurrence of BYDV serotypes in different cereals in Hungary.

\begin{tabular}{|c|c|c|c|c|c|c|c|c|c|c|c|c|}
\hline \multirow{3}{*}{$\begin{array}{l}\text { Cereal } \\
\text { species }\end{array}$} & \multirow{3}{*}{$\begin{array}{l}\text { No of samples } \\
\text { tested }\end{array}$} & \multirow{3}{*}{$\begin{array}{c}\text { No of samples } \\
\text { infected }\end{array}$} & \multicolumn{10}{|c|}{ Differentiation on BYDV serotypes } \\
\hline & & & \multicolumn{2}{|l|}{$R P V$} & \multicolumn{2}{|c|}{$R M V$} & \multicolumn{2}{|c|}{ MAV } & \multicolumn{2}{|l|}{ PAV } & \multicolumn{2}{|c|}{ SGV } \\
\hline & & & $\begin{array}{c}\text { No of } \\
\text { samples }\end{array}$ & $\%$ & $\begin{array}{c}\text { No of } \\
\text { samples }\end{array}$ & $\%$ & $\begin{array}{c}\text { No of } \\
\text { samples }\end{array}$ & $\%$ & $\begin{array}{c}\text { No of } \\
\text { samples }\end{array}$ & $\%$ & $\begin{array}{c}\text { No of } \\
\text { samples }\end{array}$ & $\%$ \\
\hline Barley & 119 & 9 & - & - & 1 & 11 & - & - & 9 & 100 & - & - \\
\hline Wheat & 297 & 32 & 3 & 9 & 12 & 37 & - & - & 17 & 53 & 1 & 3 \\
\hline Triticale & 92 & 10 & 4 & 40 & - & - & - & - & 7 & 70 & - & - \\
\hline Maize & 274 & 53 & 26 & 49 & 25 & 47 & 11 & 20 & 8 & 15 & - & - \\
\hline
\end{tabular}

In maize the RPV and RMV serotypes were present at the highest rates. It is very likely that the dominance ratio of the different BYDV serotypes changes from year to year. If the level of BYDV resistance is to be improved, this question must be examined further.

\section{DISCUSSION}

The ELISA test compensates for the disadvantages of the aphid transmission test. The use of strain-specific antisera makes the virus identification more reliable. However, Rochow (1979) states that parallel biological and serological data provide a more thorough diagnosis than can be obtained by either procedure alone.

The results obtained here in the serological tests are similar to the data of Fargette et al (1982). In Indiana, the PAV strain was also found to be the most prevalent in cereals.

Rochow (1982) made parallel tests for variants of BYDV in field-collected samples of small grains by ELISA and by aphid transmission tests with 4 vector species. Of 265 barley yellow dwarf virus isolates from 187 plants, 164 were similar to PAV, 69 resembled RMV, 20 were similar to RPV, 9 were similar to MAV and 3 resembled SGV. In Hungary, the occurrence ratios of the BYDV serotypes in cereals were almost the same and the MAV serotype did not occur at all in cereals in 1994. PAV would appear to be the most widespread serotype in cereals worldwide. The dominance ratio of this serotype is higher than those of the other 4 serotypes. This situation must be taken into consideration if the level of BYDV resistance is to be improved.

Another area of importance is the effect of BYDV serotypes on tolerant or sensitive vari- eties. There are close interactions between the BYDV serotypes and the cereals and aphid-vectors, which may cause variability in the BYDV serotypes. The ability to differentiate BYDV serotypes also leads to an understanding of some aspects of the epidemiology of the virus.

\section{ACKNOWLEDGMENTS}

The authors are grateful to É Czinka and I Kélig for their excellent technical assistance.

\section{REFERENCES}

Aapola AIE, Rochow WF (1971) Relationships among three isolates of barley yellow dwarf virus. Virology 46, 127-141

Al-Faiz C, Collin J, Comeau A, Dubuc JP, St-Pierre CA (1993) Effect of various barley yellow dwarf virus isolates on the root system of cereals. 6th Int Congress of Plant Pathol Montreal, Canada July 28August 6,86

Bertschinger $L$ (1993) Response of bread wheats and barleys to four Mexican barley yellow dwarf viruses (BYDVs) inoculated at different plant ages. 6th Int Congress Plant Pathol, Montreal, Canada, July 28 August 6, 182

Bisztray GY, Szirmai J, Szunics L (1985) Ujabb ismeretek a hazai gabonavirusokról (Abstr) Növényvédelem 8, 356

Clark MF, Adams AN (1977) Characteristics of microplate method of enzyme-linked immunosorbent assay for detection of plant viruses. $J$ Gen Virol 34, 475-483

Fargette D, Lister RM, Hood EL (1982) Grasses as a reservoir of barley yellow dwarf virus in Indiana. Plant Dis 66, 1041-1045

Gáborjányi R (1992) A gabonafélék virusbetegségei gabonavirusok. Doktori értekezés, Budapest 
Gill CC (1969) Annual variation in strains of barley yellow dwarf virus in Manitoba and the occurrence of greenbug-specific isolates. Can J Bot 47, 1277-1283

Gugerli P, Derron J (1981) L'épidémie de jaunisse nanisante de l'orge dans le bassin lémanique. Rev Suisse Agric 13, 207-211

Haase D, Proeseler G, Richter J, Eisbein K (1985) Möglichkeiten der Diagnose des Gerstengelbverzwergungs Virus. Nachrichtenbl Pflanzenschutz 39 , 52-54

Hammond J, Lister RM, Foster JE (1983) Purification identity and some properties of an isolate of barley yellow dwarf virus from Indiana. J Gen Virol 64, 667-676

Lister RM, Rochow WF (1979) Detection of barley yellow dwarf virus by enzyme-linked immunosorbent assay. Phytopathology 69, 649-654

Milinkó I, Nagy P, Rakk ZS, Dezséry M (1984) Elözetes Közlemény egy hazánkban új kukorica patogén virusról. Növényvédelem 8, 350-352

Nagy P, Milinkó I (1984) Az árpa sárga törpülés virus leküzdése. Magyar Mézögazdaság 39, 10

Nagy P, Milinkó I (1986) Adatok az árpa sárga törpeség virus hazai járványtanához. Növénytermelés 35, 493-499

Paliwal YC (1977) Rapid diagnosis of barley yellow dwarf virus in plants using serologically specific electron microscopy. Phytopathology 28, 25-36

Pocsai (1988) A gabonafélék virusbetegségei Magyarországon és diagnosztikájuk. Kandidátusi értékezés, Velence, Hungary, 1989

Pocsai E, Kobza S (1983) Epidemiological occurrence of barley yellow dwarf virus in Hungary $P$. Int Conf Integr Plant Prot Budapest 4-9 July 1, 50-57

Pocsai E, Kobza S, Dezséry M, Basky Zs (1983) Árpa sárga törpülés virus megfigyelése Fejér megyében. Növénytermelés 5, 421-426

Pocsai E, Szirmai J (1985) Effect of barley yellow dwarf virus (BYDV) infection on different barley varieties under glass-house conditions. Acta Phytopathol 20, 79-85

Pocsai E, Simonné Kiss I, Basky Zs, Dezséry M (1985) Árpa sárga törpeség virus fellépése rizsen. Abstr Nóvényvédelem 7, 308
Rochow WF (1969) Biological properties of 4 isolates of barley yellow dwarf virus. Phytopathology 59, 1580-1589

Rochow WF (1979) Comparative diagnosis of barley yellow dwarf by serological and aphid transmission test. Plant Dis Rep 63, 426-430

Rochow WF (1982) Identification of barley yellow dwarf viruses: comparison of biological and serological methods. Plant Dis Rep 66, 381-384

Rochow WF, Muller I (1971) A fifth variant of barley yellow dwarf virus in New York. Plant Dis Rep 55, 874-877

Szirmai J (1967) Uj virusbetegség gabonaföldjeinken: A sárga törpeség. Magyar Mezögazdaság 22, 19

Szirmai J (1974) Ujabb információk az árpa sárga törpeség (AST) virus epidemiologiájáról. Növényvédelem 9, 385-389

Szirmai J (1977) Az 1975 évi árpa sárga törpeség virusbetegség elmaradásának okairól. Növényvédelem 5, 210-216

Szirmai J (1987) Két hazai gabonavirus (BYDV-BMV) interferenciája. Abstr Növényvédelmi Tud Napok 1987,86

Szunics L, Szunics Lu (1980) Virus a búzán. Magyar Mezögazdaság 35, 9

Szunics L, Szunics Lu (1984) Az árpa sárga törpülés virus kártétele a búzán. Növényvédelem 4, 152-157

Szunics L, Szunics Lu, Balla L (1983) As árpa sárga törpeség virusa a búzán. Magyar Mezögazdaság 38,23

Szunics L, Szunics Lu, Pocsai E, Stehli L (1988) Az árpa sárga törpeség virus (barley yellow dwarf virus) fertözöttség hatása a búzára. Növénytermelés 37 , 211-217

Szunics L, Szunics Lu, Stehli L, Pocsai E (1991) Appearance of barley yellow dwarf virus (BYDV) on wheat in Hungary. Acta Phytopath Entomol Hung $26,87-90$

Webby GN, Lister RM, Burnett PA (1993) RMV serotypes predominate among barley yellow dwarf viruses infecting maize in Mexico. 6th Int Congr Plant Pathol Montreal, Canada, July 28-August 6, 320 